\title{
Bureaucratic Dominance in European Higher Agricultural Education
}

\author{
Emmanuel Soriano Flores
}

Universidad Autónoma Chapingo, México

\begin{abstract}
The present research work is a project of doctoral thesis of correlational type. The main objective was to demonstrate the relationship between the university bureaucracy of European Agricultural Education as a sociological phenomenon of the domain of domination according to Weber, particulary the Escuela Superior de Agricultura de Barcelona (ESAB) of the Universidad Politécnica de Cataluña (UPC) in Spain and its impact on organizational performance, as a reference and example for mexican agricultural education, particularly the Universidad Autónoma Chapingo (UACh). The results of the research validate the hypothesis: a better bureaucratic management in the context of the Spanish Higher Agricultural Education (SHAE), particularly the ESAB of the UPC, better organizational performance. Some research findings are that: students appreciate more characteristics of a leader related to legal domination, compared to traditional and charismatic; show a clear rejection towards the charismatic domination, when of politics and government is treated; validate more the practices of legal domination, compared to traditional or charismatic, when of choice of positions in the university is concerned; they reject more the bad practices related to the charismatic domination, than those related to the legal or traditional domination; and value respect, as a representative value of legal domination, in comparison with other values, such as loyalty and humility, related to traditional and charismatic domination respectively.
\end{abstract}

Keywords: bureaucracy, higher agricultural education, legal domination, organizational performance

\section{Introduction}

Higher Education in Mexico is bureaucratized to the extreme, and agricultural education is no exception, particularly the Chapingo Autonomous University (ChAU); Acosta Silva (2009) points out that although there are good intentions on the part of the leaders of the Public Universities, there is not always the way to do it, generating difference and discord between groups that legitimate or not, pretend to make their point of view prevail, which turns the university into a kind of roman coliseum. Some of the points that usually are in dispute : allocation and distribution of the budget, selection of officials, the way to held accountable, the way to evaluate and control academic and university management, among others. In that sense, he mentions that beyond the academic and the administrative, it is pertinent to study the relations of power and domination from a political perspective, to understand the accumulation of tensions that surround the university management environment. The rector as a leading figure in this management assumes three roles: "the prince" in a Machiavellian sense, "the bureaucrat" as described by Weber and "the manager" as a decision maker in the new government. His thesis holds that the accelerated changes in the highly complex and changing environment have modified the way public universities are managed with a focus on compliance with federal programs, where the autonomy of public order universities is subject to guidelines market or state, which implies administration type management, marked by the logic of a common business, but this doesn't mean raising the level and quality of education, which in the end would be desirable. In general, more investment is observed, reflected in more and better facilities, access to better technology, increased educational diversity and publications, more and more teachers with doctorates and SNI affiliates, as well as quality certifications. However, many young people still do not have access to higher education and the most worrying thing is that it seems that today the mexican graduate is not the best, or the most competitive, reflected in poor salaries and high unemployment.

However, it seems necessary and relevant to offer another view of what might appear to be a better education than the Mexican one: the European one, particularly in Spain. A brother country with which Mexico has common history ties and which apparently offers a higher education in the agricultural field completely different from Mexico, in particular that of the 
UACh, for that reason arises the interest of understanding the relations of power in the $E S A B$, to establish a point of comparison that serves as a reference in the discussion of how to govern and administer an institution as complex and important as the UACh.

The bureaucratization of education is a subject of which Spain is no stranger, since in recent years there has been talk of a change in the management of the university curriculum that transitions to the flexible, where the ideals of education are reflected in official documents to be put into practice, however, in practice it has been carried out in the form of a bureaucratic technical model that far from benefiting the educational processes and helping to achieve the proposed objectives, hampered the University Education system. For this reason autonomy has become a kind of official rhetoric, constantly questioned by an excessive bureaucratic practice particularly increased in recent years. Teaching activity is over regulated. The consequence? deprofessionalization of teaching in exchange for homogeneity in universities. The process of change has been overly rationalistic, reducing educational reforms to a top-down linear implementation, similar to applying any procedure of company procedures. In an educational ideal, the education system must provide that education that, just as pertinent and useful to solve problems, is ad hoc with the particular needs of each student, hence the criticism of the current model (Bolivar, 2012).

The educational administration as a government practice, entered Spain in its most bureaucratic stage: it is limited to regulate and control everything related to the educational process, say materials, processes, projects, initiatives, etc. ironically, one of the objectives of the educational reform in Spain was to return freedom and autonomy to the educational centers and the chair. The training and updating of teachers has traveled the same way. Everything is subordinated to a childish and simple scheme of incentives that is based on compliance and assistance. At the university level, the standardization and regulation processes controlled by the National Agency for Quality Assessment and Accreditation (ANECA) were initially not badly received. From the outset, autocratic, inbred and oligarchic practices were extinguished. However, now it is questioned whether this is really the way the University should follow in Spain (Chiva Gómez, 2014)

For Chiva Gómez (2014), a process of standardization similar to the one proposed by Mintzberg in Canada, which consists of organizations with specialized professionals (health, education, etc.), should take advantage of their abilities of these, through trusting without supervising both the expert work they do, especially without the structure assuming prominence. In a public university there are normally two communities: the academic and the administrative. The first are the teaching and research staff whose work is the raison d'être of the university: to train students and generate new knowledge. The second is the administrative and service staff whose job is to align the academic objectives to a bureaucratic regulation to make the best use of the resources and at the same time fulfill other objectives of an administrative nature. The process of normalization mentioned should fall mainly in the second group, administrative and to a much lesser extent, in academics.

At the moment there is an atmosphere of distrust towards the teaching staff and researcher, or at least this is perceived given the amount of paperwork in the form of reports and obligations that must comply. This influences their work performance, being overly regulated and attending to the bureaucratic environment that surrounds them, they are forced to work in forced marches and these results in the least of the cases, a simple stress or even suffer from a birth out.

The models to which higher education should emulate in Spain are those that are consistent with innovation and that are regulated in a necessary and not excessive way. Instead of spending their time attending courses on filling minutes or writing reports, teachers and researchers should spend their time productively and focus academically, where they are really good and helpful.

In view of the issues raised, the following research question was asked: What is the relationship between the bureaucratic management of the Spanish EAS as a form of legal domination according to Weber and its impact on organizational performance?

\section{Review of literature: from power and domination to the theory of bureaucracy}

Power and domination are social phenomena that a priori is important, relevant and necessary to study, since they cover practically the whole history of political ideas (Piñón Gaytan, 1980), are in fact the object of study of philosophy, political science, Sociology, administration, psychology and in general any discipline or area of knowledge incorporates this knowledge in its practical, in the context of modern capitalist organizations where they are exercised. 
It is interesting to make a historical approach, not necessarily in chronological order, to understand how the main theoretical contributions have been given around these concepts, to somehow visualize the emergence of the theory of domination by Max Weber (1979), The main reference of this research, that is to say, what influences had and under what paradigms and notions over time is that constructs have been generated that gave answer to the questions that was raised, especially those that have to do with "govern the other".

Many theorists have incorporated the concept of power and domination in their contributions; however, it is interesting to focus on those who have been a watershed in terms of their ideological transcendence. Some Americans, most European with emphasis on the German school. It is pointed out that some might have been omitted not because of intentionality but because of the diversity and theoretical breadth of understanding these themes. On the other hand, the orientation of this synthesis is mainly philosophical and to a lesser extent sociological, since although the political theory bases its theoretical corpus on these subjects, it is considered necessary to understand them from different conjunctures, either that of those who exercise them, of whom The sufferers or of who or who explains its genesis and its consequences.

Among the important referents on these issues, Machiavelli is mentioned at first, who focuses on power in a perverse way, similar to Nietzsche who in turn defines it as a natural instinct that starts from the need to control the other. Hobbes, Locke, and Aristotle appreciate it as a political necessity to organize as a society, once differences and individualities cannot be overcome. Aristotle is perhaps the most advanced understanding of this political power, since his ideological approach is the basis of most of the models of government in the different countries of the world. Parsons on the other hand gives a more economic and administrative touch.

In a deeper philosophy and dialectic Hegel and Heidegger appreciate, a complete reflection of being based on the fear of death. Chomsky also agrees with the fear, however, the difference lies in the anti-imperialist stance of this, in that sense and with an anti-dominance approach we find several theorists; Marx, the main one of them, his economic approach is the basis; on the other, Gramsci, Bourdieu and Fromm coincide with the critical approach to domination. Gramsci does it from the cultural hegemony, Bourdieu from the social fields and the habitus. An anti-domination approach that is a musthave reference is the Frankfurt School, of which Horkheimer and Adorno were quoted; who question the use of reason in the exercise of power and Fromm does sofrom psychoanalysis.

Finally, Max Weber defines power as the probability of imposing will on others. This action takes place in the ordinary social dynamics of individuals and, before the imposition of some, there is resistance from others, that is, the condition of imposition carries an opposing force for resistance or "non-submission" in various types of manifestations. Probability is important, whereas, imposing will, does not guarantee that this will happen, since it will depend on the conditions and context in which it is wanted to carry out such imposition, so power is exercised in theory the most strong, the fittest, the most astute, and those who, in one way or another, surpass the others, and even though their will is something different from what is imposed upon them. The difference between power and domination lies in the legitimacy, that is, in the conscious or unconscious acceptance of those to whom the will of the dominator is imposed, versus power, where it carries

a resistance, therefore the main theme in the study of power Of Weber, lies in the acceptance of this, to be a form of domination. The more acceptances has an imposition of will, the more legitimacy it will have, therefore, power becomes domination. The three types of domination that Weber describes are charismatic, legal and traditional.

Charismatic domination is based on faculties such as: magic, heroism, intellectual or speaking ability. The devotion and loyalty to charismatic leaders is related to the novel, the unusual, the never seen and their total commitment to certain causes. The purest types are the prophet, the prominent warrior, and the demagogue. The basis of this domination is the communication that is established with the followers. Whoever obeys is assimilated to an apostle and the one who commands is assimilated to a caudillo. The caudillo is followed by his outstanding qualities and not by tradition or by any statute. Traditional domination comes from the belief of "lordly" ideology. The most representative form is the patriarchy, which issues commandments is the "lord" and who obeys are the "subjects", on the other hand, relies on the servants, who make up the government body. The values that prevail in this type of domination are loyalty and fidelity. Orders are in line with tradition. It is not possible to create an alternative and different regulation; therefore, traditional domination is "forever". For its part, legal domination, finds the bureaucracy as its purest form. The basic postulate is that the rules governing a community can be created and modified as often as necessary, as long as it adheres to the established form. The occupants of legal domination are elected or appointed, and these actors in turn define the limits in which they must govern. The methodical activities, the powers of command and the strict fulfillment of the duties are the characteristic features of the 
bureaucracy, also known as magistrate. In the public sphere has developed in the political and ecclesiastical sphere mainly, in the private sector, companies are the best representation of the bureaucracy. It is based on the principle of functional hierarchy and, once it has reached its full development and potential, has a monocratic orientation. Likewise, the bureaucracy is, in essence, of a documentary type. In modern life the bureaucratic life separates from the office, from the office staff.

Theoretical approaches vary, although those rescued in this research were primarily philosophical as well as sociological. It went deeper into the approach to power and domination found in them, although some of the cited theorists describe, explain and embrace other fields of human knowledge. With the exception of Aristotle and Machiavelli, Locke and Hobbes, thinkers were approached mainly in the nineteenth and twentieth centuries, emphasizing that the historical moments that determined them were those given by the industrial revolution, capitalism, technological development, as well as some misfortunes.

Given the theoretical analysis made, it was possible to infer that the forms of power and domination have changed over time and their ways of understanding them as well as they will continue to do especially in the paradigm of changes of the 21 st century, where technology and modification in structures and globalization, are the extra components to continue to theorize about these concepts.

\section{Purpose of the study}

The object of study of research is the relations of power and domination in the EAS, and Max Weber's sociological theory and its rational-legal-bureaucratic derivation were chosen as the most pertinent to explain such relations, by the validity and applicability of Theory and by its hierarchy in the political and social sphere. Therefore, the general objective is written as follows:

To analyze the relations of power and domination in the EAS of Spain through a bureaucratic diagnosis in the ESAB of the UPC to know its impact on the organizational performance.

From the general objective the following specific objectives emerged:

To know the opinion of the students regarding the actions that should promote the maximum authority of the ESAB of the UPC: the rector.

Identify the type of domination according to Max Weber's typology, with the most identified students of the ESAB of the UPC.

\section{Methodology}

The research is qualitative, and the scope is correlational, which aims to know the relationship that exists in two variables: university bureaucracy and organizational performance. The methodological design, as well as the compilation of the state of knowledge, were carried out in 2014, 2015 and early 2016, empirical data were collected during a 6-month research stay (second half of 2016) conducted at the Faculty of Education of the University of Barcelona.

The first variable, university bureaucracy, was measured through an in-depth interview with a high official of the ESAB of the UPC: the head of studies and; the other, organizational performance was measured with a questionnaire of 17 items applied to 74 students of the agricultural engineering careers of the third semester and landscape engineering of ninth. To achieve representativeness it was considered:

- Apply the questionnaire to students of at least two different grades, out of the four grades

- Apply the questionnaire to students from initial semesters and advanced semesters

- Apply the questionnaire to at least ten percent of the student population, which is equivalent to 71 students out of the 710 currently enrolled, according to data provided by ESAB boss of studies

\section{Results}

Regarding the variable "university bureaucracy", the interview with the boss of studies of the ESAB of the UPC lasted approximately an hour and forty minutes, was made in his office, after consultation. Asked if he cared if his name was 
mentioned in the interview, he first mentioned that he did not, but later he said that he preferred to avoid it. The form of analysis was validating whether or not it meets criteria of good bureaucratic management, previously defined.

\begin{tabular}{|l|l|l|}
\hline Canon & Find & Evaluation \\
\hline University legislation & $\begin{array}{l}\text { The rules are not strictly followed and, instead, a bureaucratic pragmatism is } \\
\text { practiced }\end{array}$ & $R$ \\
\hline Communication & $\begin{array}{l}\text { The formal communication, only occurs in meetings or trades, towards } \\
\text { the students is via email. }\end{array}$ & $R$ \\
\hline Division of Labour & $\begin{array}{l}\text { In order to hold a position of relevance and connotation in the ESAB, as a boss of } \\
\text { studies, class hours are removed from the official, who is in principle a teacher, and } \\
\text { also that the time load they have in class is not excessive. }\end{array}$ & G \\
\hline Authority and responsibility & $\begin{array}{l}\text { The functions are well delimited for the position of the boss of studies, he even } \\
\text { showed an organization chart where, according to his explanation, it is perfectly } \\
\text { clear that each one, there is a high degree of } \\
\text { flexibility that allows to adapt or delegate certain functions, the pay is good, but at } \\
\text { another time was better. }\end{array}$ & $G$ \\
\hline Administrative procedures & $\begin{array}{l}\text { There is great control and precision in administrative procedures, in addition to } \\
\text { communication and alternatives for students, even for those } \\
\text { who are irregular. }\end{array}$ & $G$ \\
\hline $\begin{array}{l}\text { Human resources (recruitment } \\
\text { and development) }\end{array}$ & $\begin{array}{l}\text { For the occupation of a position of civil servant in the ESAB, it is necessary } \\
\text { experience like academic secretary and the vocation for positions of administrative } \\
\text { type. }\end{array}$ & $R$ \\
\hline Level of teaching staff & The majority are recognized professors and researchers & $G$ \\
\hline Problems at university & Lack of resources and prior mismanagement & $R$ \\
\hline
\end{tabular}

$\mathrm{G}=\operatorname{good} \mathrm{R}=\operatorname{regular} \mathrm{B}=$ bad

Therefore, the variable university bureaucracy was positively evaluated by having the majority of criteria evaluated in a good and regular way

Regarding the variable "organizational performance", the results of the questionnaire applied to ESAB students are shown below.

- The majority of the students are in the range of 17 to 23 years, of these, the 22 year olds were the majority with 20 , followed by those of 17 and 18 years old. The oldest student is 50 years old and there are 6 students in the 25 to 50 age range, the rest, that is 68 , are in the range of 17 to 24 and 44 of the respondents were men, for 30 women

- $\quad 44$ students are of the Agricultural Engineering degree, by 30 of the degree in landscaping.

- $\quad$ The majority of the students consider useful and necessary to know the university legislation, a few consider it indispensable and the less irrelevant.

- The management of the University's procedures, most of the students, think are good

- The attention that the students receive in the areas of process management, 50 of 74 think they are kind and know what they do, the rest sees some lack in attention, competence or both

- $\quad$ Most students think that the administrative environment works generally well, 26 thinks it is bad, although it has salvageable things and the less they see it very well or very badly.

- $\quad 39$ students consider that the academic life is partially affected by the problems of the University, 29 do not know or have the perception that they do not exist and the least think that they do not affect the academic life or that they affect it totally.

- $\quad 60$ of the 74 respondents usually know who to turn to when they have doubts about paperwork and processes, and they solve it quickly 
- $\quad 72$ out of 74 students corroborate that the information is mostly written

- $\quad 50$ of the 74 students have the perception that the University workers perform their work in a comfortable and relaxed way

- Most students believe that teachers give the right amount of classes, 21 believe that the amount is too much or too little.

- 63 of 74 students have good perceptions about the performance of their teachers

- Most students consider that teachers evaluate according to regulations and have an adequate degree of flexibility

- The students show a decisive rejection to the kings of Spain and to the presidential figure, 24 of the 74 respondents answered slogans of independence in favor of Catalonia.

- Most students believe that the rector should promote that selection processes are rendered with justice

- Most students consider that to be the rector of the University, they must have been democratically elected, rather than demonstrate confidence andleadership.

- $\quad$ The value that students consider most important to hold a position of power in the University is respect, above loyalty and humility.

\section{Conclusions and discussion}

With regard to the general objective

Analyze the relations of power and domination in the EAS of Spain through a bureaucratic diagnosis in the ESAB of the UPC to know the impact on the organizational performance. The analysis of the two variables measured in a correlational way is done as follows:

In relation to the variable "university bureaucracy" it can be deduced, based on the interview made to the head of studies of the ESAB of the UPC and contrasting the answers with the theory of the bureaucracy of Weber:

- It is important and is considered the experience in the occupation of the administrative positions.

- $\quad$ The work load for the official's work is adequate in most cases.

- $\quad$ There is control and precision in the indicators of university management.

- There is a good communication of the administrative area towards the students.

- The university legislation is not followed to the letter, but the praxis has adapted to the academic and administrative needs of the students.

- The formal communication is good, although it can improve because much of the administrative communication is given orally.

- $\quad$ Bad bureaucrats were fired and good ones continued to function

- The functions are well delimited and there is an adequate degree of flexibility that allows to make decisions for different scenarios.

- $\quad$ There is a problem of decentralization and division of labor at the level of UPC and other campuses

- The level of payment and satisfaction is good overall and reflected in the work.

Evaluating most of the criteria in a positive way, it is validated that the university bureaucracy in the ESAB of the UPC, is good in general.

In relation to the variable "organizational performance" it can be said, based on the applied survey and contrasting the answers with the theory of the bureaucracy of Weber:

- $\quad$ The majority of the students consider that the school procedures are agile, fast and simple in ESAB

- Most students believe that the management of the ESAB in the different areas is good.

- $\quad$ Most of the students believe that the administrative scope of ESAB is good

- Most students believe that internal problems partially affect the academic management of ESAB, some of them are not aware of such problems. 
- $\quad$ Most students know who to turn to when in doubt about paperwork

- $\quad$ Information to students is given in writtenform

- Most of the students believe that the work of ESAB employees is relaxed and comfortable

- $\quad$ Most students believe that their teachers provide adequate hours of class.

- Most students believe that their teachers are experts or very good at the subjects they teach.

- $\quad$ Most students believe that their teachers evaluate them appropriately

When evaluating the different items positively, it can be inferred that the variable "organizational performance" is evaluated in a good way.

\section{Therefore, the Hypothesis is Valid, Better Bureaucratic Management in the Context of the Eas of Spain, Particularly the Esab of the Upc, Better Organizational Performance.}

In relation to specific objectives

Know the opinion of the students regarding the actions that should promote the maximum authority of the ESAB of the UPC: the rector, the students answered that:

- The rector must, in the main, avoid that in the positions for which a competition is held for a place in the ESAB, processes are not taken fairly; Followed by preventing anyone who does not fulfill a job profile, do so; And finally that places are given for friends and family. The first option is related to charismatic domination, the second with legal domination and the third with traditional domination. Therefore, it can be inferred that the greater rejection that the students manifest, is towards bad practices from the charismatic domination, second, it is towards the bad practices from the legal domination, and, third, it is towards the bad practices from the charismatic domination.

- The students consider that, to be rector of the UPC, must have been chosen democratically in the first place; Then, show confidence and leadership; And, lastly, that he has been involved with officials in order to have experiences. These answers are related to legal, charismatic and traditional domination respectively, therefore, it can be inferred that the students consider that the way to come to power from the rectory in ESAB, is in that order.

- The students considered that the respect, linked to legal domination, is the value that the principal of the UPC should promote; Followed by loyalty, linked to traditional domination, and, finally, humility, linked to charismatic domination.

Identifying the type of domination according to Max Weber's typology, with the most identified students of the ESAB of the UPC, the students answered according to a series of desirable qualities in the official, which are related to some kind of Domination: legal, charismatic or traditional, previously identified as follows:

The sum of the qualities related to charismatic domination is 230 , that of the qualities related to traditional domination are 199 and that of the qualities related to legal domination, gives 311 in the sum total, i.e., students stand out more Qualities related to legal domination compared to the other two. Faced with the questioning of which authority is most identified, the response was overwhelming; 50 students prefer some independent aspirant to the power of Spain, which is related to the charismatic domination; No student identified himself in the king and queen of Spain, who represent traditional domination; And the same case of the president of Spain, which represents legal domination. On the other hand, some answers, which certainly had no option in the questionnaire, were alluded to the total rejection of the king and queen of Spain, alluding to the independence of Catalonia and wrote it in Catalan, not in Castilian. It is important to mention that the political climate experienced in connection with the elections held in 2016 in Spain, in which there was a great climate of discontent, due to the fact that it was necessary to wait several months to choose a leader, See with the answers to the questionnaire. What evidently was reflected in the answers is the nationalist and independentism feeling of Catalonia, due to the history of control and domination that, according to some Catalans, Spain has exerted like invading nation during a long time.

\section{References}

[1] Acosta Silva, A. (2009). Príncipes, burócratas y gerentes. El gobierno de las universidades públicas en México.México: ANUIES 
[2] Ajuntament de Barcelona. Sectores estratégicos 2016. Recuperado de http://web.archive.org/web/20131109175151/http://w42.bcn.cat/web/es/per-que-barcelona/sectorsestrategics/index.jsp

[3] Alcoberro, R. (2000) Introducción a Max Weber. Recuperado de http://www.alcoberro.info/V1/Weber.pdf

[4] Andretich, G. (2009) Relaciones de poder: un análisis cualitativo a partir del proceso de elección de modalidades en escuelas públicas de Rafaela en el marco de la reforma de los '90, Edición electrónica gratuita. Recuperado de www.eumed.net/libros/2009c/604/

[5] Birch, S. (1995). Sociología. Caracas: Fondo Editorial UNA

[6] Bolívar, A. (2012). El proceso de burocratización de la escuela. Revista Crítica. Número 22

[7] Bourdieu, P. (2000). La dominación masculina. Barcelona: Anagrama

[8] Bourdieu, P. (1988). La distinción. Madrid, Taurus.

[9] Chiavenato (2007). Introducción a la teoría general de la Administración. México: Mc Graw Hill

[10] Chiva Gómez, R. (2014). ¿Queremos una universidad burocrática o innovadora? El país. Edición noviembre de 2014

[11] Chomsky, N. (2004). Los dilemas de la dominación. Buenos Aires: Clacso

[12] Chomsky. N. (2004). Decálogo de la manipulación mediática. Recuperado de https://elobservatoriodeltiempo.wordpress.com/2011/10/09/chomsky-decalogo-de-la-manipulacion-mediatica/

[13] Datos generales de España en 2015. Recuperado de www.wikipedia.com/España

[14] Datos generales de Barcelona en 2015. Recuperado de www.wikipedia.com/Barcelona

[15] Educación Agrícola Superior en España. Recuperado de www.infoagro.com/educación

[16] Etchegaray, R. (2000). Dominación y política. La plata: Ediciones al margen

[17] Fayol, H. (1987). Administración general e industrial. Buenos Aires: El ateneo

[18] Foucault, M. (1992). Microfísica del Poder. Madrid: La Piqueta

[19] Fromm, E. (2008). El miedo a la libertad. Barcelona: Paidos Ibérica

[20] Gramsci, A. (1977). Antología. México: Siglo XXI

[21] Gramsci A. (1972). Notas sobre Maquiavelo. Buenos Aires: Nueva Visión

[22] Grinnnell, R.M. (1997) Social work research and evaluation: quantitative and qualitative approaches. Itaca:

[23] Peacock Publishers

[24] Grueso Caicedo (2009). Análisis de Percepción sobre la Burocracia Pública: Una Aproximación a un Estudio de Caso en el Plan de Estudios Políticos Y Resolución de Conflictos de la Universidad del Valle (Tesis de doctorado). Universidad del Valle de Colombia. Recuperado de http://bibliotecadigital.univalle.edu.co/bitstream/10893/3834/4/CB-0449511.pdf [24] 2006, 2007,2008

[25] Gouldner, A. (1979). La sociología actual: renovación y crítica. Madrid: Alianza

[26] Hegel, F. (2000). Fenomenología del espíritu. México: Fondo de Cultura Económica

[27] Heidegger, M. (1951). El ser y el tiempo. México: Fondo de Cultura Económica

[28] Hernández Sampieri, R.; Fernández-Collado, C.; Baptista Lucio, P. (2006). Metodología de la investigación. México: McGraw Hill

[29] Hindess, B. (1996). Discourses of Power: from Hobbes to Foucault. Oxford: Blackwell

[30] Hobbes, T. (1987). El Leviatán. México: Nuevo Mar Editores

[31] Horkheimer M. y Adorno T. (1998). Dialéctica de la llustración. Fragmentos filosóficos. Madrid: Trotta

[32] Horkheimer M. (2002). Crítica de la razón instrumental. Madrid: Trotta

[33] Hyppolite. J. (1970). Introducción a la filosofía de Hegel. Buenos Aires: Calden

[34] Información general de la Escuela Superior de Agricultura de Barcelona de la Universidad Politécnica de Cataluña (2016). Recuperado http://esab.upc.edu/ca

[35] Información sobre la estructura organizativa y los centros de investigación de la Universidad Politécnica de Cataluña (2016). Recuperado de www.upc.com

[36] Información general de la Universidad Politécnica de Cataluña (2016). Recuperado del sitio www.wikipedia.com

[37] Información general de la Fundación CIM (2016). Recuperado del sitio http://www.fundaciocim.org/

[38] Información general de la Fundación Centro de Innovación y Tecnología (2016). Recuperado del sitio http://cit.upc.edu/

[39] Información general de la Fundación Politécnica de Cataluña (2016). Recuperado del sitio http://www.fpc.upc.edu/

[40] Información general del Parque de Investigación e Innovación de la Universidad Politécnica de Cataluña (2016). Recuperado del sitio http://www.upc.edu/parcupc/ 
[41] Información general de la UPCnet de la Universidad Politécnica de Cataluña (2016). Recuperado de http://www.upcnet.es

[42] Katz, D., y Kahn, R.L. (1966). The social psychology of organizations. Nueva York: John Wiley

[43] López Zavala, R. (2003). El valor del liderazgo para el cambio universitario. Recuperado de http://www.redalyc.org/comocitar.oa?id=34003805

[44] Marcuse, H. (1993). El hombre unidimensional. México: Planeta

[45] Marsal, F. (1970). Conocer Max Weber y su obra. España: Dopesa

[46] Marx, K. (1987). Miseria de la filosofía. México: Siglo Veintiuno

[47] Marx, K. (1995). El capital: crítica de la economía política. Tomo 1. México: Fondo de Cultura Económica

[48] Marx, K. (1980). La filosofía de El capital. Madrid: Taurus

[49] Maquiavelo, N. (1983) El príncipe. Barcelona: Planeta.

[50] Merton, R. (1959). Burocracia y racionalidad en las organizaciones de Weber. Nueva York: Mc Graw Hill

[51] Ministerio de Agricultura, Alimentación y Medio Ambiente del Gobierno de España 2016

[52] Recuperado de http://www.lamoncloa.gob.es/espana/eh15/agricultura/Paginas/index.aspx

[53] Nietzsche, F. (1981). Genealogía de la moral. Barcelona: Laia.

[54] Nietzsche, F. (1994). La voluntad de poderío. Madrid: Edaf.

[55] Nietzsche, F. (1993). Así habló Zarathustra. Madrid: Alianza Editorial.

[56] Noguera Fernández, S. (2011). La teoría del estado y el poder en Antonio Gramsci: claves para descifrar la dicotomía Dominación-Liberación. Nómadas. Revista Crítica de Ciencias Sociales y Jurídicas. Recuperado de http://dx.dol.org/10.5209/rev_NOMA.2011.V29.n1.26799

[57] Osorio Parraguez, A. (2012) Nietzsche: la voluntad de poder. Recuperado de http://www.andresosorio.cl/filosofia/autores/friedrich-nietzsche/6-nietzsche-la-voluntad-de-poder.html

[58] Páez Díaz de León, L. (2001). La teoría Sociológica de Max Weber. Ensayos y Textos. Ciudad de México:Porrua

[59] Parsons, T. (1969). El aspecto político de la estructura y procesos sociales. en Easton, D. (2004) Enfoques sobre teoría política. Buenos Aires: Amorrortu

[60] Piñón Gaytán, R. (1992). La filosofía del poder: Maquiavelo y Hobbes. Conferencia dictada en la UAM Xochimilco el 3 de noviembre.

[61] Ramos Erazo, R. (2005). Organización burocrática, gestión eficiente y modernización de la universidad pública, el caso de la Universidad Nacional Mayor de San Marcos. (Tesis doctoral). Facultad de Ciencias Administrativas de la UNAMS. Recuperado de http://cybertesis.unmsm.edu.pe/bitstream/cybertesis/1476/1/Ramirez_er(1).pdf

[62] Reale, G. (2003). Introducción a Aristóteles. Barcelona: Herder

[63] Ribas, J. (1998). En defensa de Maquiavelo. El Salvador: Revista Realidad.

[64] Sarum, M. (1992). Nietzsche y la educación. Revista de Educación número 297. Londres: Goldsmith's College

[65] The Global Competitiveness Report 2015-2016. Foro Económico Mundial de Davos Suiza 2015. Recuperado de www.weforum.org

[66] Touchard, J. (1983). Historia de las ideas políticas. Madrid: Tecno

[67] Urbano, F. (2007). Weber: Historia del pensamiento filosófico. Murcia: Siglo XX

[68] Warren, G. (1975). El declive de la Burocracia y las Organizaciones del futuro. Sao Paulo: Edgar Blucher

[69] Weber, Ma. (1995). Biografía de Max Weber. México: Fondo de Cultura Económica

[70] Weber, M. (S.F.). ¿Qué es la burocracia? Argentina: Taurus

[71] Weber, M. (1979). Economía y sociedad. México: Fondo de Cultura Económica

[72] Wolf, E. (2001). Figurar el poder: Ideologías de dominación y crisis. México: Ciesas 